\title{
MODELING THE DISCIPLINE "TRANSLATION THEORY” ACCORDING TO THE CULTURAL PECULIARITIES
}

\author{
E.S. Balandina, balandinaes@susu.ru \\ T.Yu.Peredrienko, peredrienkoti@susu.ru \\ South Ural State University, Chelyabinsk, Russian Federation
}

\begin{abstract}
Contemporary linguistics embraces diverse complex issues, with the linguistic aspects of interlingual speech activity (translation) being a key one. Discipline "Translation theory" is considered to be an important aspect of learning process that is included into the integrated approach of foreign language teaching. Nowadays a lot of foreign students from foreign countries decide to continue their education in Russia. Thus, Russian educational institutions have to adapt their programs according to the demands of new students. Foreign language department of South Ural State University offers to complete the program 45.04.01 "Philology", that allows students working as teachers, translators and researchers in the field of linguistics and philology after the graduation. "Translation theory" is included into the obligatory list of subjects as it helps to establish connections between the source language and target language and to compare not only language forms, but also worldviews. The main aim of the article is to present the perception of the translation by Arabic students, the organisation peculiarities and the structure of the course "Translation theory", to set up the goal of the course, to select the most significant topics that help Master students to get acquainted with the Russian translation theory. By using a mixed methods approach the authors also offer interesting tasks that could be given to students for individual work and enumerate difficulties that they come across during the implementation of the course. In conclusion, the most important competences that are formed during this discipline are presented.
\end{abstract}

Keywords: foreign students, competence, translation theory, incomplete sentences method.

\section{Introduction}

Nowadays the international student mobility is considered to be an important part of modern higher education policy. A lot of students from Arabic countries come to Russia to get higher education, thus the question connected with the discipline organization peculiarities arises. The main difficulty that the teaching staff has to overcome is connected with the fact that students from Iraq are not adopted to the Russian pedagogical system and don't understand quite well how lectures and seminars are organized. Thus, they are tired to write too much and can't get used to study a lot, find additional information themselves. So the main aim is to help them in adjusting to the new academic environment, new culture and to teach them the basis of the scientific research.

The perception of the term translation and organization peculiarities of the discipline "Translation theory" form the main concept of the article. Translation being both the practice and the result of a communicative act occupies a special place among the practical skills of foreign language study. Translation is crucial for cross-cultural understanding as it reveals ideologies, policies, and social experiences. That is why the students specializing in linguistics should pay a particular attention to the development of their theoretical and practical translation skills.

This paper aims to present the structural model of the discipline. According to the curriculum, the classroom work takes 54 hours ( 36 hours for lectures and 18 for seminars). A greater number of hours per lecture is explained by a large amount of theoretical ma- terial necessary to be explained. The goals of the course can be formulated as follows:

- to identify the main goal of the discipline;

- to state the main competences that are formed in the course of the study;

- to select the general topics;

- to offer various research tasks that can be given to students.

\section{Methodology}

In recent years in the majority of modern studies mixed-methods approaches have gained popularity. The term "mixed methods" refers to a methodology of "mixing" quantitative and qualitative data analysis within a single research. Such approach permits a more complete utilization and description of data than separate quantitative and qualitative data collection and analysis do.

In order to estimate the general perception of translation we used the method of unfinished sentences, where the respondents were given the unfinished sentences like "Translation is_ " and asked to finish them. Through their endings we got the chance to analyse important characteristics of the studied concept.

To construct the content of the discipline we organized the written test where the students were asked to answer the questions connected with the general and private translation theories. This test helped to select the material that should be covered during the lectures, seminars, or individual students work. Thanks to observation as an active acquisition of information and the feedback questionnaire that was 
given to the students at the end of the course we evaluated the most useful and interesting research tasks that allowed students to develop their scientific skills.

\section{Results and discussion}

The general perception of translation is revealed by the following semantic groups constructed in the course of the unfinished sentence experiment.

- Sematic group of difficulty: something difficult; complicated;

- Semantic group of process: when you translate; translation from different languages; lator;

- Semantic group of the doer of the action: trans-

- Semantic group of educational process: a new discipline.

Therefore, we can say, that students evaluate translation as something difficult and complicated, although in their answers we didn't come across any professional terms that reveal the deep understanding of the studied process.

That is why the main goals of the course "Translation theory" in the Master program 45.04.01 "Philology" [4] were formulated as follows:

1) to inform foreign students about the basic principles of translation studies;

2) to familiarize students with the history of translation activity;

3) to introduce the basic concepts that are used to describe the translation process, the problems of general and private translation theories;

4) to discuss the assessment criteria of the translation quality;

5) to compare basic principles of translation of different nations;

6) to consolidate the theory in practice.

As for the content of the discipline, it can vary according to numerous needs and wants. However, during the first practical class it is recommended to organize the discussion about some general questions connected with the main principles of translation theory or to give the test that will allow the teaching staff to estimate the level of knowledge that students have after the graduation from the Bachelor program. Therefore, the topics covered within the discipline can be modified according to the results shown by the listeners.

In our practice, the Arabic students have quite good knowledge concerning the history of Arabic translation theory, some general concepts, text pragmatics and translation norms. At the same time, they do not understand a wide range of fundamental questions connected with the adequate and equivalent translation, translation strategies, lexical, grammatical and complex transformations.

According to the received data, we present the following structure of the discipline "Translation theory".

1) History of translation and general concepts of translation

Arabic students know a lot of information about with the history of Arabic translation theory, however, their knowledge is limited by the theoretical aspects within one culture. Therefore the purpose of this sec- tion is to introduce the most important and significant concepts of Russian and European science in the field of translation.

2) Adequate and equivalent translation

The analysis of the texts translated by the Arabic students shows that they have little understanding of the differences between adequate and equivalent translation. The mistakes made by them can be divided into two types.

The first type of mistakes occurs in the situation when students simply don't understand the meaning of the translated text and can not preserve the communicative goal in the target text. As a rule, in this case there is no equivalence between the individual parts of the original abstract and the translation.

The second type of mistakes occurs in the situation when a student wants to be as accurate as possible thus translating everything word for word, establishing the equivalence between individual parts of the text and completely forgetting about the main communicative purpose of the utterance. This mistake is more typical for the Arabic students who tend to preserve the structure of the English sentence and translate everything according to the grammatical, lexical and syntactic norms of the English language. So the main goal of a teacher is to introduce various levels of equivalence and explain that the hierarchy of levels does not imply the degree of evaluation.

3) Translation techniques

This section is considered to be the most difficult for the Arabic students, as they are not so good at applying various transformations in the translation process. During the lectures and seminars devoted to this topic students are given the opportunity to learn a lot about lexical, grammatical and complex transformations. Table 1 shows the most challenging and difficult techniques for the Arabic students that demand the particular attention in the process of education. The figures presented in the tables show the percentage of tasks that coursed difficulties.

4) Text pragmatics and functional styles

In this section students get acquainted with such questions as the concept of pragmatics, author's communicative intention, communicative effect upon the receptor, translators impact, language and speech functions. The listeners are given the task to select the distinctive features of various functional styles and to study the samples of translation belonging to different registers.

5) Translation norms and quality control of a translation

In the last section students discuss questions that are connected with the professional ethics, etiquette, code of professional conduct, protocol ceremonies. They are given the examples of various translated samples and are asked to evaluate the quantity of the target text.

Theoretical and practical knowledge is also accompanied by various research tasks performed during seminars that allow students to look deeper into the translation process. Table 2 shows the scheduling of hours by lecture and seminar topics. 
Лингводидактика

Transformation techniques and the percentage of tasks that coursed difficulties

\begin{tabular}{|l|l|c|}
\hline \multicolumn{1}{|c|}{ Transformation } & \multicolumn{1}{|c|}{ Types of technique } & Percent \\
\hline \multirow{5}{*}{ Grammar transformations } & Grammar substitution & 27 \\
\cline { 2 - 3 } & Word order change & 25 \\
\cline { 2 - 3 } & Sentence portioning & 10 \\
\cline { 2 - 3 } & Sentence integration & 31 \\
\cline { 2 - 3 } & Grammar compensation & 4 \\
\hline \multirow{5}{*}{ Lexical transformations } & Specification & $5 \%$ \\
\cline { 2 - 3 } & Generalization & 24 \\
\cline { 2 - 3 } & Modulation & 13 \\
\cline { 2 - 3 } & Differentiation & 21 \\
\cline { 2 - 3 } & Compensation & 33 \\
\cline { 2 - 3 } & Metaphoric transformations & 19 \\
\hline \multirow{5}{*}{ Complex transformations } & Explicatory translation & 10 \\
\cline { 2 - 3 } & Reduction & 9 \\
\cline { 2 - 3 } & Integral transformation & 21 \\
\cline { 2 - 3 } & Antonymic translation & 22 \\
\cline { 2 - 3 } & Metonymic translation & 19 \\
\cline { 2 - 3 } & Complex compensation & 22 \\
\hline
\end{tabular}

Scheduling of hours by lecture and seminar topics

\begin{tabular}{|l|c|c|}
\hline \multicolumn{1}{|c|}{ Topic } & $\begin{array}{c}\text { Lecture } \\
\text { (hours) }\end{array}$ & $\begin{array}{c}\text { Seminar } \\
\text { (hours) }\end{array}$ \\
\hline History of translation and general concepts of translation & 4 & 2 \\
\hline Adequate and equivalent translation & 6 & 4 \\
\hline Translation techniques & 10 & 4 \\
\hline Text pragmatics and functional styles & 8 & 4 \\
\hline Translation norms and quality control of a translation & 8 & 4 \\
\hline
\end{tabular}

On the first stage of the course students are given the task to analyse the work of various translation services that could be used by a translator: GoogleTranslate, Bing Translator, Babylon, babelxl, WorldLingo, Prompt, imTranslator.net, etc. As a result of this analysis students select the most comfortable and functional services that they are going to use in their practice.

One of the most interesting projects is connected with the role of the dominant cultural ideas in Arabic translation tradition. It is well-known that the translation process is not just translation of lexical units and grammar constructions, it is a cross-cultural event [3]. Culture creates the basis for the people's worldview [2]. The central place of the worldview is occupied by the notion of the dominant cultural idea - the governing idea, main distinguishing feature and part of culture that constitutes the common way to see and perceive the world [1]. Dominant cultural ideas play an important role in the translation process as they influence the general translation strategies and the choice of translation techniques. So the students are asked to analyse the role of the Arabic dominant cultural idea from synchronic perspectives.

To complete the task the students can find any text written by the English or American writers that was translated at the end of the XX century or at the beginning of the XXI. The aim of the research is to reveal the differences between the source and target texts and explain a translator's choice. Thus, the listeners are to make a detailed comparative analysis of texts with regard to lexis, grammatical constructions, syntax, and style. In conclusion, they should select the most vivid examples of translation techniques influenced by the dominant cultural idea.

Another variant of the research task that is also connected with the cultural peculiarities can sound like "Translation and culture: Stylistic devices as cultural bumps". In this case, students are asked to deal with the particular stylistic devices, e.g. metaphor, metonymy, epithets, etc. and analyse the ways of their translations. In this project it is preferable to give students the texts belonging to different functional styles so to see the peculiarities in the choice of the translations techniques.

The feedback questionnaire shows that although such research tasks are thought to be rather difficult and time-consuming for the Arabic students, they consider them to be useful. Such tasks help to form the skills that are acquired to complete the projects: the ability to organize the scientific study, to formulate the goal and to plan the scientific research, to analyse 
the literature connected with the research, to see various transformation techniques that were used by the translators and to explain their choice, to work in a team and to find a way for solving various scientific tasks.

At the end of the course students are offered to complete the final tests that include theoretical questions covering all the material discussed during the lectures and seminars. The results of the tests show how good the students are at applying their knowledge.

\section{Conclusion}

As a result of the discipline study students learn to differentiate various expressive means, stylistic devices, and various functional styles; to apply various transformations; to generate statements adequate to the required communicative goal; to give an adequate translation of the source text; to search for the information in the references, specialized literature and computer networks; to make an oral and written translation according to the lexical, grammatical, syntactic and stylistic norms. The discipline "Translation theory" provides students with the ability to create, edit, summarize and transform various texts belonging to all types of official, business and journalistic registers. They also study to compare their national "Theory of translation" with the European, American and Russian one.

\section{References}

1. Kononenko B.I. Bol'shoj tolkovyj slovar' po kul'turologii [Cultural Studies. Big Definition Dictionary]. - Moskva: Veche, 2003. - 512 p.

2. Tarasov E.F. Aktual'nye problemy analiza yazykovogo soznaniya [Relevant problems of linguistic consciousness study]. Yazykovoe soznanie i obraz mira [Linguistic consciousness and the worldview]. M., 2000. - S. 24-32.

3. Vermeer, H.J. Theory of Translation (Some arguments for and against). - Heidelberg: TEXTconTEXT, 1996. - 132 p.

4. Master program 45.04.01 "Philology". Retrieved from URL http://fgosvo.ru/news/7/1483

Ekaterina S. Balandina, Candidate of Philology, Associate Professor, Department of Foreign Languages, South Ural State University (national research university), Chelyabinsk, balandinaes@susu.ru

Tatiana Yu. Peredrienko, Candidate of Philology, Associate Professor, Department of Foreign Languages, South Ural State University (national research university), Chelyabinsk, peredrienkoti@susu.ru

Received 20 December 2018

Удк $81 ' 255+378,44$

DOI: $10.14529 /$ ling 190108

\title{
МОДЕЛИРОВАНИЕ УЧЕБНОГО КУРСА «ТЕОРИЯ ПЕРЕВОДЧЕСКОЙ АРГУМЕНТОЛОГИИ» С УЧЕТОМ КУЛЬТУРНЫХ ОСОБЕННОСТЕЙ СТУДЕНТОВ
}

\author{
Е.С. Баландина, Т.Ю. Передриенко \\ Южно-Уральский государственный университет, г. Челябинск, Россия
}

Современные тенденции мобильности в образовании вывели вопросы межъязыковой речевой деятельности в современной лингвистике на первый план. Дисциплина «Теория переводческой аргументологии» считается важным аспектом учебного процесса и входит в комплексный подход обучения иностранному языку. В настоящее время многие иностранные студенты решают продолжить обучение в России. Таким образом, российские учебные заведения начинают адаптировать свои программы в соответствии с потребностями и культурными особенностями новых слушателей. Кафедра иностранных языков Южно-Уральского государственного университета предлагает обучение по программе 45.04.01 «Филология». В данной программе «Теория переводческой аргументологии» входит в обязательный список предметов, поскольку помогает установить связь между исходным языком и языком перевода, а также сравнить не только языковые нормы, но и представления о мире. Цель данной статьи состоит в изучении представления арабских студентов о понятии перевода, выделении основных особенностей образовательного процесса с иностранными слушателями, представлении различных научных материалов и проектов для индивидуальной работы. В заключение авторы выделяют наиболее значимые компетенции, которые формируются в ходе освоения дисциплины.

Ключевые слова: иностранные студенты, компетенция, теория перевода, метод незаконченных предложений. 


\section{Лингводидактика}

\section{Лumepamypa}

1. Кононенко, Б.И. Большой толковый словарь по культурологии / Б.И. Каноненко. - М.: Вече, 2003. $512 c$

2. Тарасов, Е.Ф. Актуальные проблемы анализа языкового сознания / Е.Ф. Тарасов // Языковое сознание и образ мира. - М., 2000. - C. 24-32.

3. Vermeer, H.J. Theory of Translation (Some arguments for and against) / H.J. Vermeer. - Heidelberg: TEXTconTEXT, 1996. - 132 p.

4. Приказ Министерства образования $и$ науки РФ от 3 ноября 2015 2. № 1299 «Об утверждении федерального государственного образовательного стандарта высшего образования по направлению подготовки 45.04.01 Филология (уровень магистратуры)». - http://fgosvo.ru/news/7/1483.

Баландина Екатерина Сергеевна, кандидат филологических наук, доцент кафедры иностранных языков, Южно-Уральский государственный университет (Челябинск), balandinaes@susu.ru

Передриенко Татьяна Юрьевна, кандидат филологических наук, доцент кафедры иностранных языков, Южно-Уральский государственный университет (Челябинск), peredrienkoti@susu.ru

Поступила в редакцию 20 декабря 2018 2.

\section{ОБРАЗЕЩ ЦИТИРОВАНИЯ}

Balandina, E.S. Modeling the Discipline "Translation Theory" According to the Cultural Peculiarities / E.S. Balandina, Т.Yu. Peredrienko // Вестник ЮУрГУ. Серия «Лингвистика». - 2019. - Т. 16, № 1. - C. 48-52. DOI 10.14529/ling 190108

\section{FOR CITATION}

Balandina E.S., Peredrienko T.Yu. Modeling the Discipline "Translation Theory" According to the Cultural Peculiarities. Bulletin of the South Ural State University. Ser. Linguistics. 2019, vol. 16, no. 1, pp. 48-52. DOI: 10.14529/ling190108 